\title{
Barremian-Aptian Biostratigraphy in Yazd Block, Central Iran
}

\author{
Reza Hanifzadah1, Koorosh Rashidi2 ${ }^{*}$, Mahnaz Amir Shahkarami3 \\ ${ }^{1}$ Department of Geology, Faculty of Science, Tehran Science and Research Branch, Islamic Azad University, \\ Tehran, Iran \\ ${ }^{2}$ Department of Geology, Payam Noor University, Ardakan, Iran \\ ${ }^{3}$ Department of Geology, Payam Noor University, Vazvan, Iran \\ Email: hanif.464@gmail.com, ${ }^{*}$ koo.rashidi@gmail.com, shahkarami@gmail.com
}

Received 9 May 2015; accepted 15 June 2015; published 18 June 2015

Copyright (C) 2015 by authors and Scientific Research Publishing Inc.

This work is licensed under the Creative Commons Attribution-NonCommercial International License (CC BY-NC). http://creativecommons.org/licenses/by-nc/4.0/

(c) (i) (8) Open Access

\section{Abstract}

The Lower Cretaceous benthic Limestone in Yazd Block (Central Iran zone) is known as the Taft and Shahkuh Formations. In this study, the age of the Taft and Shahkuh Formation, is examined based on biostratigraphic and paleontological investigations of Taft Formation in sections of Herisht (NE Ardakan) and Abanbar (NE Ardakan) and Shahkuh Formation in Chahpalang section (North Ardakan). According to the lithostratigraphic investigations, the taft and Shahkuh Formation in these sections include of thin bedded to medium bedded and massive limestone. Micropaleontology study of the Taft and Shahkuh Formation has led to the recognition of numerous genus and species which belong to Orbitolinidae Families such as: Dictyoconus pachymarginalis, Montseciella arabica, Mesorbitolina parva, Paleodictyoconus sp., Paleodictyoconus actinostoma, Palorbitolina sp., Palorbitolina lenticularis, Praeorbitolina cormyi, Praeorbitolina cf. wienandsi, Praeorbitolina claveli, Praeorbotolina sp., cf. Paleodictyoconus sp., Palorbitolina ultima. and Calcareous Algae such as: Acroporella sp., Acroporella cf. Radoičićae, Actinoporella sp., Arabicodium sp., Arabicodium cf. elongates, Augioporella cf. fouryae, Bacinella irregularis, Bueina sp., Boueina cf. hochstetteri, Boueina minima, Bueina cf. pygmaea, Cayeuxia sp., Cayeuxia anae, Garwoodia sp., Garwoodia cf. maxima, Girvanella sp., Griphoporella aff. Cretacea, Halimeda sp., Kopedagaria sp., Kopedagaria sphaerica, Lithocodium aggregatum, Marinella sp., Montiella elitzae, Marinella lugeoni, Marinella cf. yogoslavica, Neomeris sp., Neomeris cf. cretacea, Neomeris cf. pfenderae, Parachaetetes asvapatii, Permocalculus sp., Permocalculus dragastani, Permocalculus minutes, Pseudoactinoporella sp., Pseudoactinoporella iranica, Pseudoactinoporella cf. iranica, Pycnoporidium lobatum, Rivularia sp., Salpingoporella sp., Salpingoporella cf. patruliusi, Salpingoporella cf. johnsoni, Salpingoporella pygmaea, Salpingoporella mehlbergii, Salpingoporella aff. Turgida, Salpingoporella cf. dinarica, Suppiluliumaella cf. praebalkanica, Udotea flabellum. Based on the identified Microfossil, such as Orbitolinid fossil, the age of the Taft Formation in the Kuh-e Herisht is assigned to Upper Barremian-Middle Aptian, and in the Abanbar area is determined as Upper Barremian-Lower Ap- 
tian, at least the age of the Shahkuh Formation in the Chahpalang area is determined as Upper Barremian-Lower Aptian.

\section{Keywords}

Lower Cretaceous, Limestone, Calcareous Algae, Orbitolinidae Family, Biostratigraphy, Shahkuh Formation, Taft Formation

\section{Introduction}

The cretaceous strata with benthic facies in north east of Ardakan, known as Taft formation at Herisht and Ab anbar area,and this strata in north Ardakan (Chahpalang Area), known as Shahkooh Formation. These bentic sediments include a few meters of very thick to massive and relatively fossiliferous limestone. "However, their detailed stratigraphy, depositional environments and palaeontology are poorly known in exception of Cretaceous ammonites, which have been recorded and described from numerous localities”, Wilmsen et al. [1]-[2]. As litostratigraphy characteristics of Yazd Block is the existence of shallow-marine carbonates belonging to Barremian-Aptian, which is known as the Taft and Shahkuh Formation in this block (Figure 1).

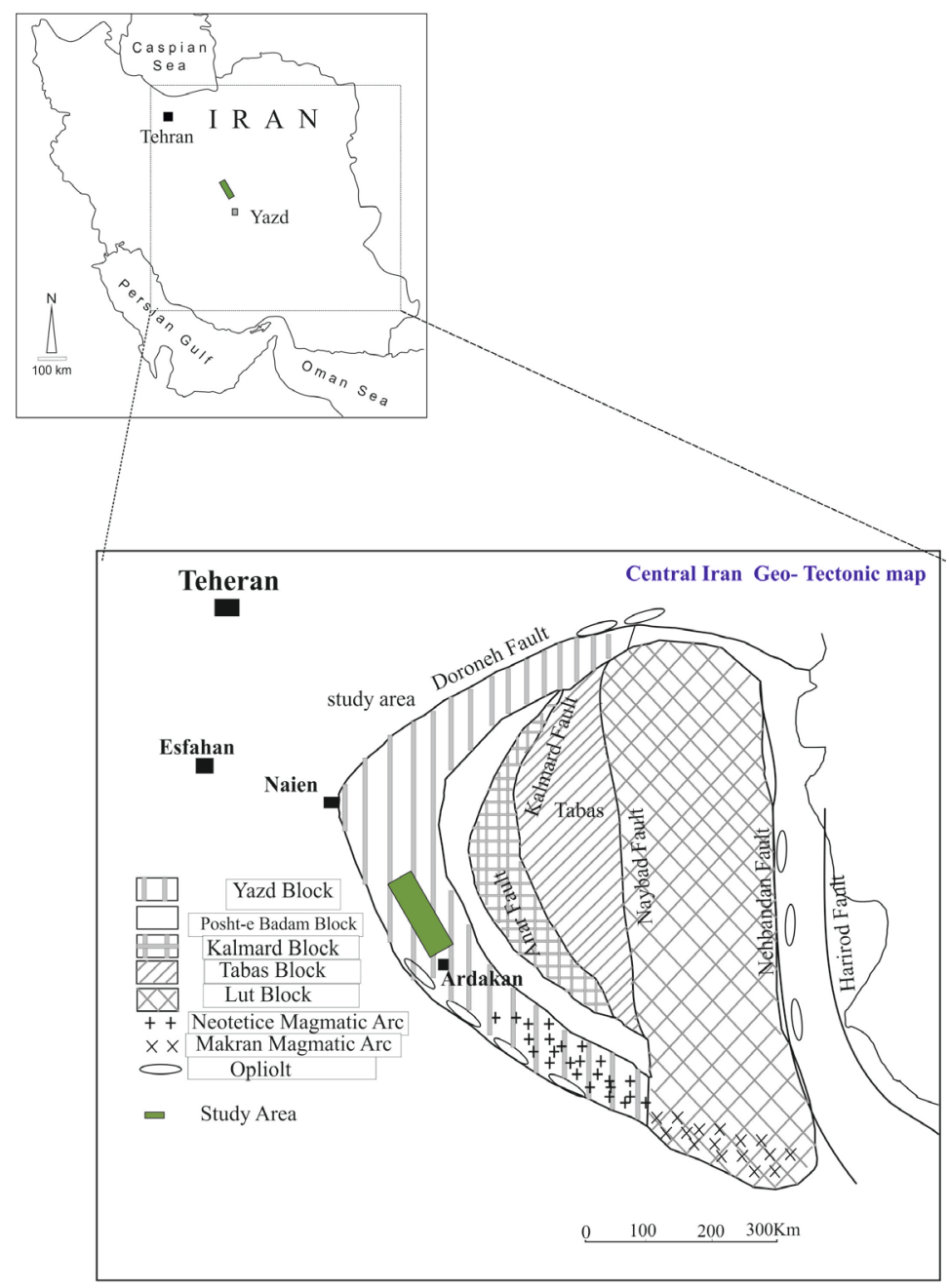

after: Aghanabati 2004 in Persian

Figure 1. Study area in Central Iran zone (after Aghanabati 2004 [3]). 
"It is the regional development of a widespread carbonate unit colloquially known in Iranian geology as 'Orbitolina limestones', which crops out, for example, in the Koppeh Dagh (Tirgan Formation), the Alborz (Tizkuh Formation), SW Iran (Daryan Formation) or the Yazd area (Taft Formation)” Wilmsen et al. [1]-[2]. The scope of the present paper is the description and stratigraphic dating of the Taft and Shahkuh Formation in North and North east Ardakan area. Furthermore, the Taft and Shahkuh Formation, is an important piece in the complex mosaic of Barremian-Aptian carbonate systems which should be considered for future palaeo-bio-geographic reconstructions.

\section{Geological and Geographical Setting}

The study area belongs to the Central-East Iranian Microcontinen Central "Iran consists of several tectonic blocks, i.e., the Yazd, Tabas and Lut Blocks. Study area located at West of Yazd Block” Wilmsen et al. [1]-[2] (Figure 1). Cretaceous limestone in this block include of two carbonaceous facies, one of them, known as Oceanic or Plagic facies , include of plagic limestone and marl that deposited from Lower to Middle Cretaceous at open sea and in stratigraphy literature known as Biabanak Shale, the other carbonaceous facies include of Bentic limestones that known as Orbitolin limestone , and deposited from Lower to Middle Cretaceous at Carbonaceous Platform Environment.this thin to thick beded Bentic limestones are strongly fossiliferous and in this Block, and in regard of lithostratigraphy unit, famous as Taft Formation in east and center of Yazd Block, and Shahkuh Formation at west of this Block, the Shahkuh Formation (Aistov et al. [4]), consisting of thick-bedded to massive, often dark-coloured, micritic limestones (wacke-, pack-, rud- and floatstones) with abundant orbitolinid foraminifera and rudists, This formation is up to $400 \mathrm{~m}$ thick, cliff-forming and has been assigned a Barremian-Aptian age (Aistov et al. [4]). Taft Formation (Nabavi [5]), consisting of thick-bedded to massive rudist-, algae- and orbitolinid-bearing shallow-water limestones.

The three sections that selection for Biostratigraphy study (Figure 2), one of them (Chahpalang Section) as litostratigraphy properties, is equal with Shahkuh Formation, and another sections (Herisht and Abanbar Section) is equal with Taft Formation (Figure 2).

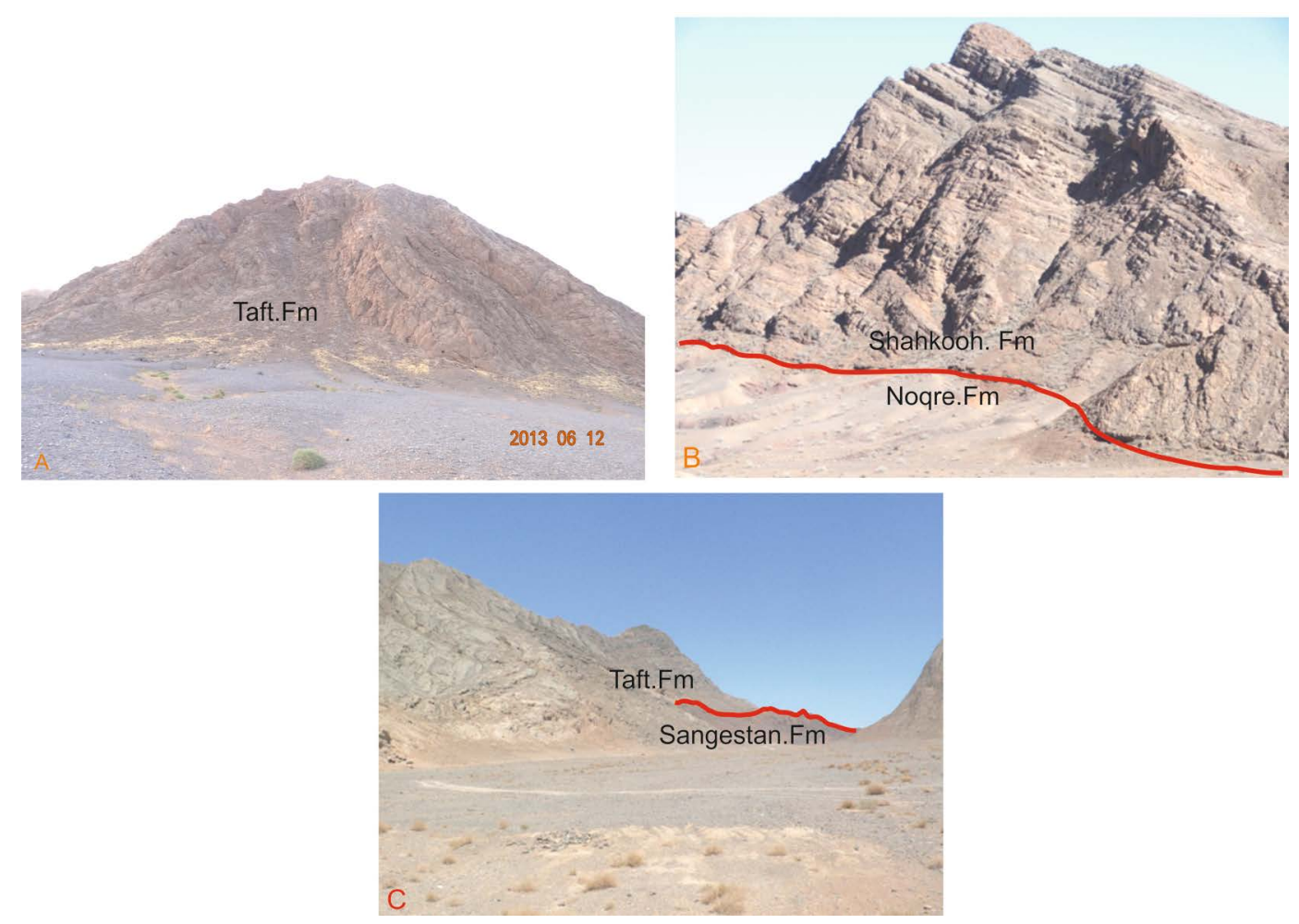

Figure 2. Field photographs showing: (A) Taft Formation at Abanbar section. (B) Shahkooh Formation and boundries with Noqre Formation in lower part at Chahpalang section. (C) Taft Formation and boundries with Sangestan Formation in lower part at Herisht section. 
As discussed, the material studied comes from three different stratigraphic sections, one situated at North and the two others located at North east of Ardakan (Figure 2): (A) Ab anbar sections (Figure 2 \& Figure 3): These section is located about $21 \mathrm{~km}$ Northeast of Ardakan (coordinates: 32 $20^{\prime} 26.82^{\prime \prime N}, 54^{\circ} 13^{\prime} 7.52 " \mathrm{E}$ ). (B) Chah palang section (Figure 2 \& Figure 3): (coordinates: 33 $5^{\circ} 19.2^{\prime \prime N}, 54^{\circ} 10^{\prime} 28.94^{\prime \prime E}$ ). This section located about 110 km North of Ardakan. (C) Herisht section (Figure 2 \& Figure 3): This section located about $12 \mathrm{~km}$ Northeast of Ardakan (coordinates: $32^{\circ} 25^{\prime} 37.61^{\prime \prime N}, 54^{\circ} 6^{\prime} 29.26 " \mathrm{E}$ ).

\section{Material and Methods}

In order to establish biozones, three stratigraphic columns were selected. Fieldwork on three stratigraphic sections led to the description of detailed lithostratigraphic characteristics and measurement of the thickness of each stratigraphic section. The lower and upper lithostratigraphic limits of the studied stratigraphic sections were determined by fieldwork on $495 \mathrm{~m}$ of Taft Formation (Barremian-Aptian) sediments in the Kuh-e Herisht and 465 $\mathrm{m}$ of these Formation sediments in Ab anbar area (NW) and at least, $243 \mathrm{~m}$ of Shahkuh Formation sediment in Chahpalang area that were selected for this study. 350 samples collected from three selected stratigraphic sections.These samples were collected in base of vertical change in lithofacies and biofacies at any stratigraphy column of slected section. Then thin sections were made from the collected samples.

\subsection{Biostratigraphy}

The vertical distribution of foraminiferal taxa and calcareous algae at any stratigraphy column of selected section,

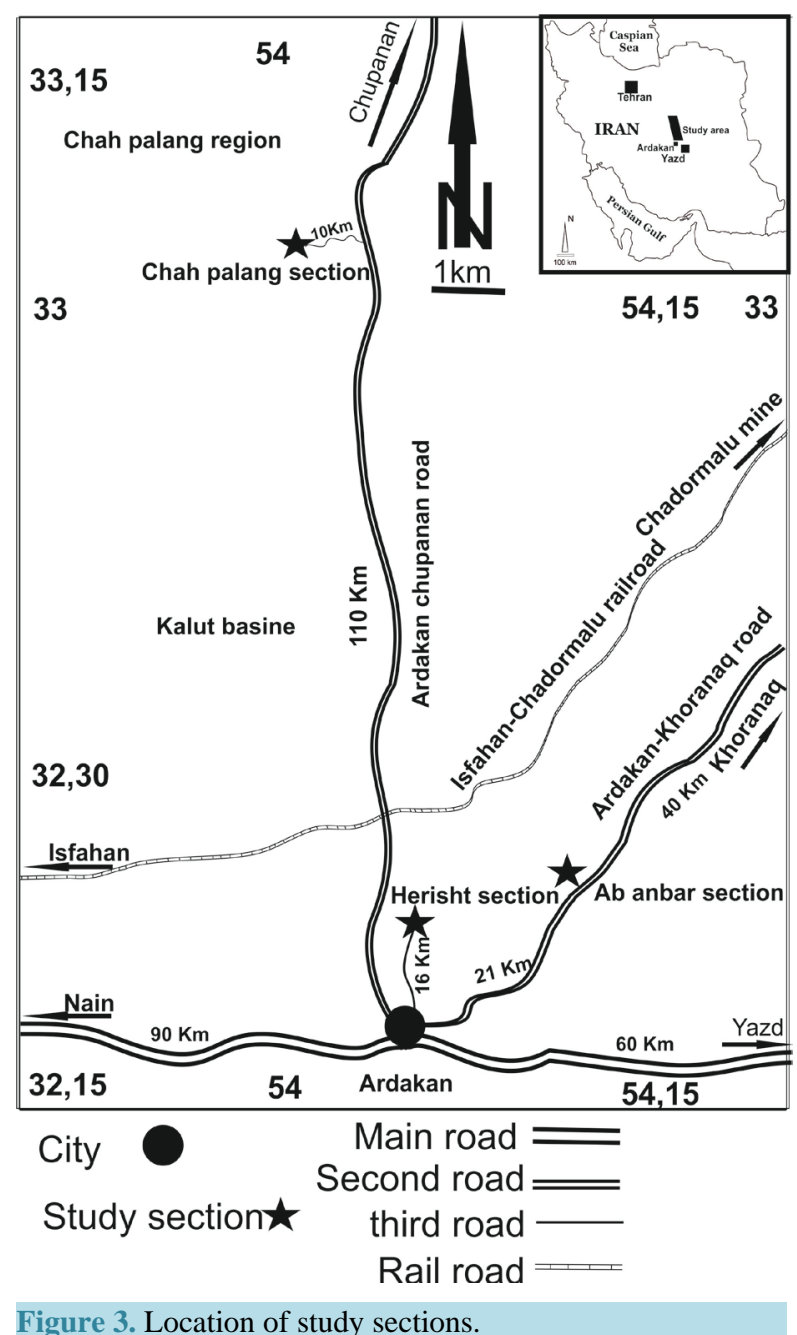

Figure 3. Location of study sections. 
cused that definition, different biozones for each of the stratigraphic sections. Foraminifera in particular are important biostratigraphical tools as index microfossil, because they typically have the rapid evolution, abundant and widespread distribution, and suddenly extinction, in contrast with Orbitolinidae Family, Calcareous Algae have not all trait of index microfossil, as resulted the genus and species belong to this group, difficulty are recognised. However In this study, 8genus and 9 species from Orbitolinidae Family, 16 genuses and 31 species from calcareous algae were recognised. The stratigraphic distribution of Foraminifera (Orbtolinidae Family and Calcareous algae taxa, supports three Orbitolinid and Algal biozones from three studied sections (Ab anbar, Chah palang and Herisht stratigraphic section). The vertical distribution of Foraminifera and Calcareous Algae in three sections indicates that benthic microfossil is well developed in the lower to upper part of the Taft and Shahkuh Formation stratigraphic sections.

\subsection{Ab anbar Biostratigraphy}

The two biozones established in this stratigraphic section are numbered as biozones 1 \& 2:

Biozone 1: also recognised as "Orbitolinid Biozone" include of (Dictyoconus pachymarginalis, Montseciella arabica, Palorbitolina sp., Cf. Paleodictyoconus sp., Paleodictyoconus actinostoma, Palorbitolina sp., Palorbitolina ultima, Assemblage zone).

Biozone 2: also recognised as "Algal Biozone” include of (Acroporella sp., Actinoporella sp., Arabicodium sp., Bacinella irregularis, Cayeuxia sp., Lithocodium aggregatum, Montiella elitzae, Marinella lugeoni, Salpingoporella cf .dinarica, Assemblage zone).

Orbitolinid Biozone: This biozone is marked by the first appearance of Dictyoconus pachymarginalis and Montseciella arabica. The lithologic characteristic of this biozone consists of cream and grey medium-thikness bedded and massive limestone with a thickness of $465 \mathrm{~m}$. Common foraminifers of this biozone include in: Dictyoconus pachymarginalis, Montseciella arabica, Palorbitolina sp., Cf. Paleodictyoconus sp., Paleodictyoconus actinostoma, Palorbitolina sp., Palorbitolina ultima.

The Dictyoconus pachymarginalis (Plate 1, F.2, 4, Plate 2, F.5) as index Orbitolina species is reported by many autors from many localities, such as Schroeder [6]. Who in first time reported from Alborz Mountains with purpose age of Aptian-Lower Albian, Masse et al., 1992, reported from NE Spain with propose age of Lower Gargasian, Yazdi-Moghadam [7], also Roozbahani [8] reported this species from Central Iran zone, Schlagintweit [9], reportes this species from Taft formation in Herisht section, s and proposed the Bedulian-Gargasian for it, and at least, Schlagintweit [10], reported this Microfauna from upper part of Taft formation in type locality and Lower-Middle Bedulian age purposed for it. He confirmed that, this Microfauna is idex Microfossil of North Neo Tethian area. The Montseciella arabica (Plate 1, Figs.1, 5-7) as other index Orbitolina reported by many authors from many locality, such as Clavel [11] reported from south France and Jurra Mountain in Swiss area, with puropse age of Upper Barremian-Early Lower Aptian for it, in comparison with known Ammonite biozone, also Schroeder [12], reported this Microfauna from East of Arabian Plate, s and purposed the Upper Barremian-Early Lower Aptian age for it, The other index Orbitolin Fossils which is present at above Biozon, s, have the same time, such as two index Orbitolin that described before. Thus, The Barremian-Aptian age is purposed for this Bizone. As lithologic result, this biozone studied in cream to grey thick bedded limestones with thickness of $465 \mathrm{~m}$.

Algal Biozone: This biozone is marked by the first appearance of Lithocodium aggregatum (Plate 2, F12) and Montiella elitzae (Plate 3, F.8), The other Calcareous Algae of this biozone are, Acroporella sp., Actinoporella sp., Arabicodium sp., Bacinella irregularis, Cayeuxia sp., Lithocodium aggregatum, Montiella elitzae, Marinella lugeoni, Salpingoporella cf. dinarica, In base of time range of index Calcareous Algae, such as Montiella elitzae, Salpingoporella cf. dinarica and etc, the late Barremian to early Aptian age suggested for this biozone so as regarded this time, from studied of before biozone (Orbitolinid biozone) (Figure 4).

Actually, common lithofacies and biofacies of this section comprise benthic packstone to wackestone. Well developed benthic biofacies of this section support the lagoon paleoenvironment in this time (late Barremian to early Aptian) at investigated area.

\subsection{Chah Palang Biostratigraphy}

The two biozones established by distribution of Orbitolinidae family and Calcareous Algae in this stratigraphic section are numbered as biozones 1 \& 2 (Figure 5): 


\section{Plate 1}
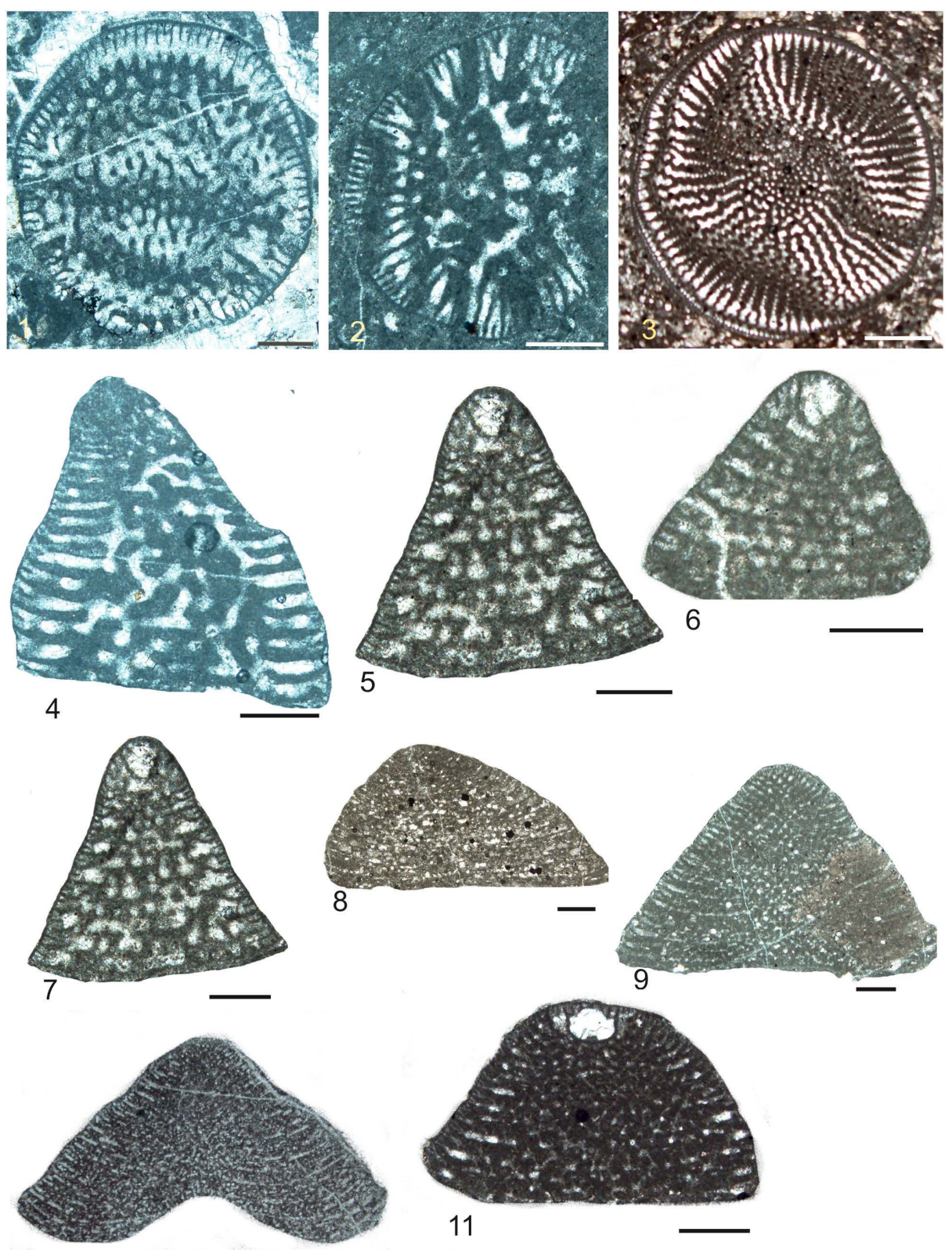

11
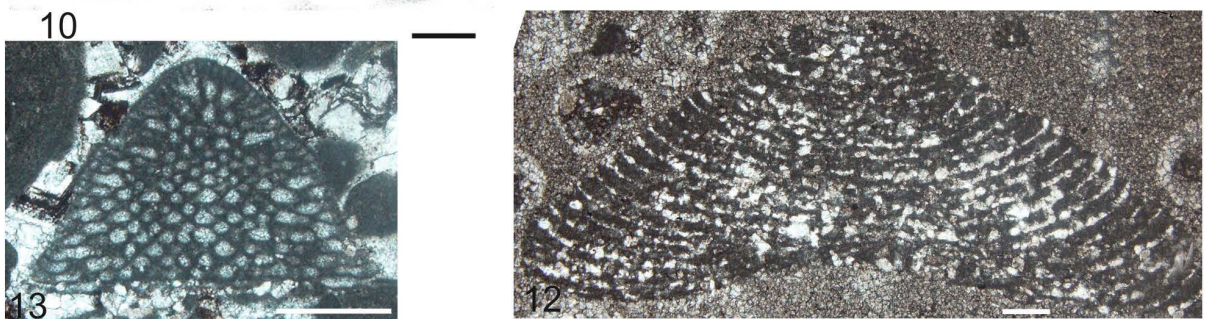

Plate 1. 1. Montseciella arabica, transverse oblique section, 2. Dictyoconus pachymarginalis, transverse oblique section, 3. cf. Paleodictyoconus sp., transverse section, 4. Dictyoconus cf. pachymarginalis, longitude section, 5-7. Montseciella arabica, longitude section, 8. Palorbitolina SP., longitude oblique section, 9, cf. Paleodictyoconus sp., longitude oblique section, 10. Paleodictyoconus actinostoma. longitude oblique section, 11. Palorbitolina ultima. longitude section, 13. Praeorbitolina sp. longitude oblique section. Scale bar represent, $0.3 \mathrm{~mm}$. 

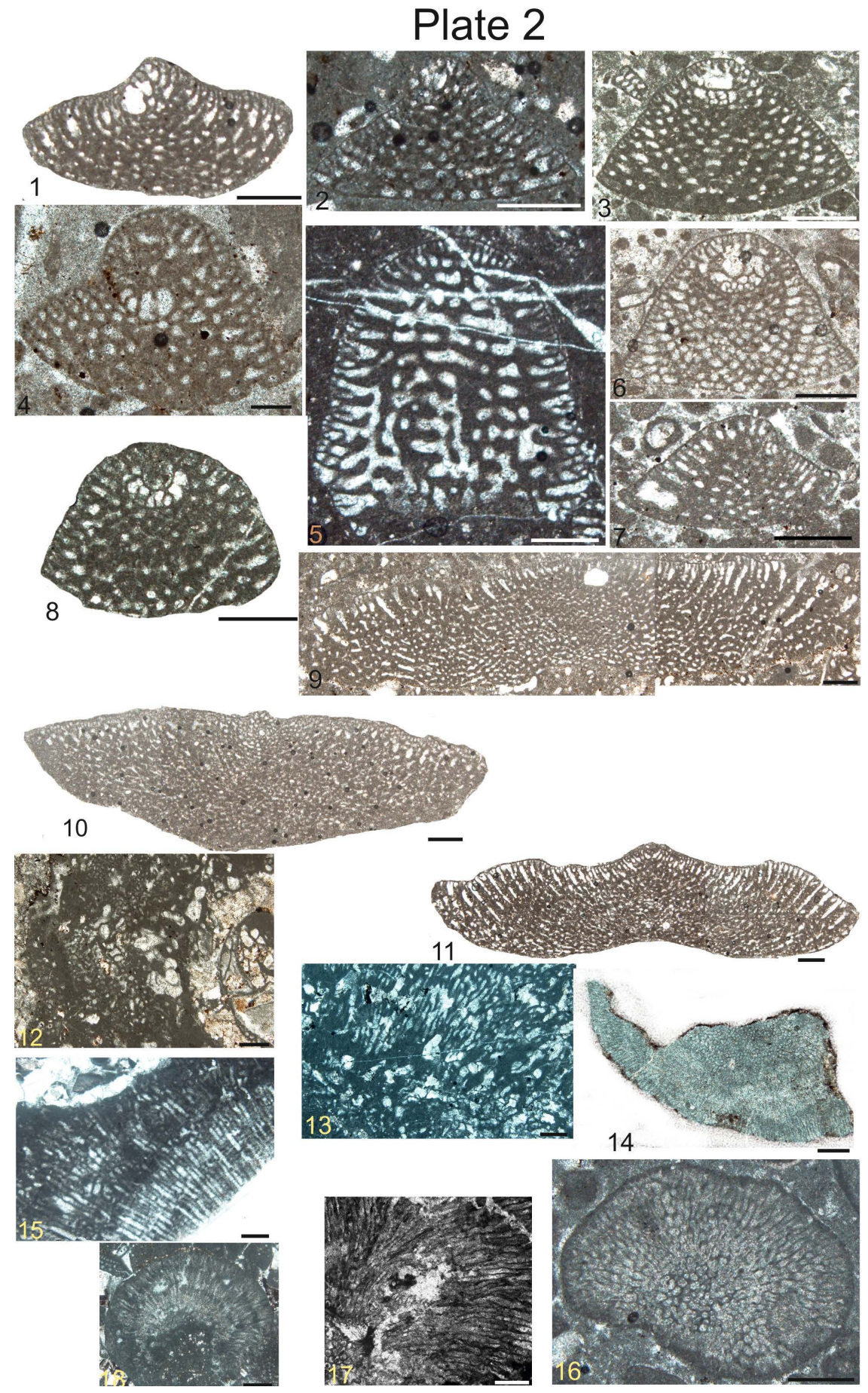

Plate 2. 1, 4. Praeorbitolina cormyi, longitude section, 2. Praeorbitolina claveli. longitude section, 3, 6, 8, Mesorbitolina parva. longitude section, 5. Dictyoconus pachymarginalis. longitude oblique section, 7. Praeorbitolina cf. wienandsi longitude tangential section, 9. Palorbitolina lenticularis, longitude section, 10. Paleodictyoconus actinostoma. longitude section, 11. Palorbitolina SP., longitude oblique section, 12. Lithocodium aggregatu, Bacinella irregularis, transverse section, 13. Cayeuxia sp. longitude slightly oblique section, 14. Pycnoporidium lobatum, longitude slightly oblique section, 15. Parachaetetes asvapatii. longitude oblique section, 16. Girvanella sp. longitude slightly oblique section, 17. Garwoodia sp. longitude slightly oblique section, 18. Garwoodia $\mathrm{cf}$ maxima. longitu slightly oblique section. Scale bar represent, $0.3 \mathrm{~mm}$. 


\section{Plate 3}
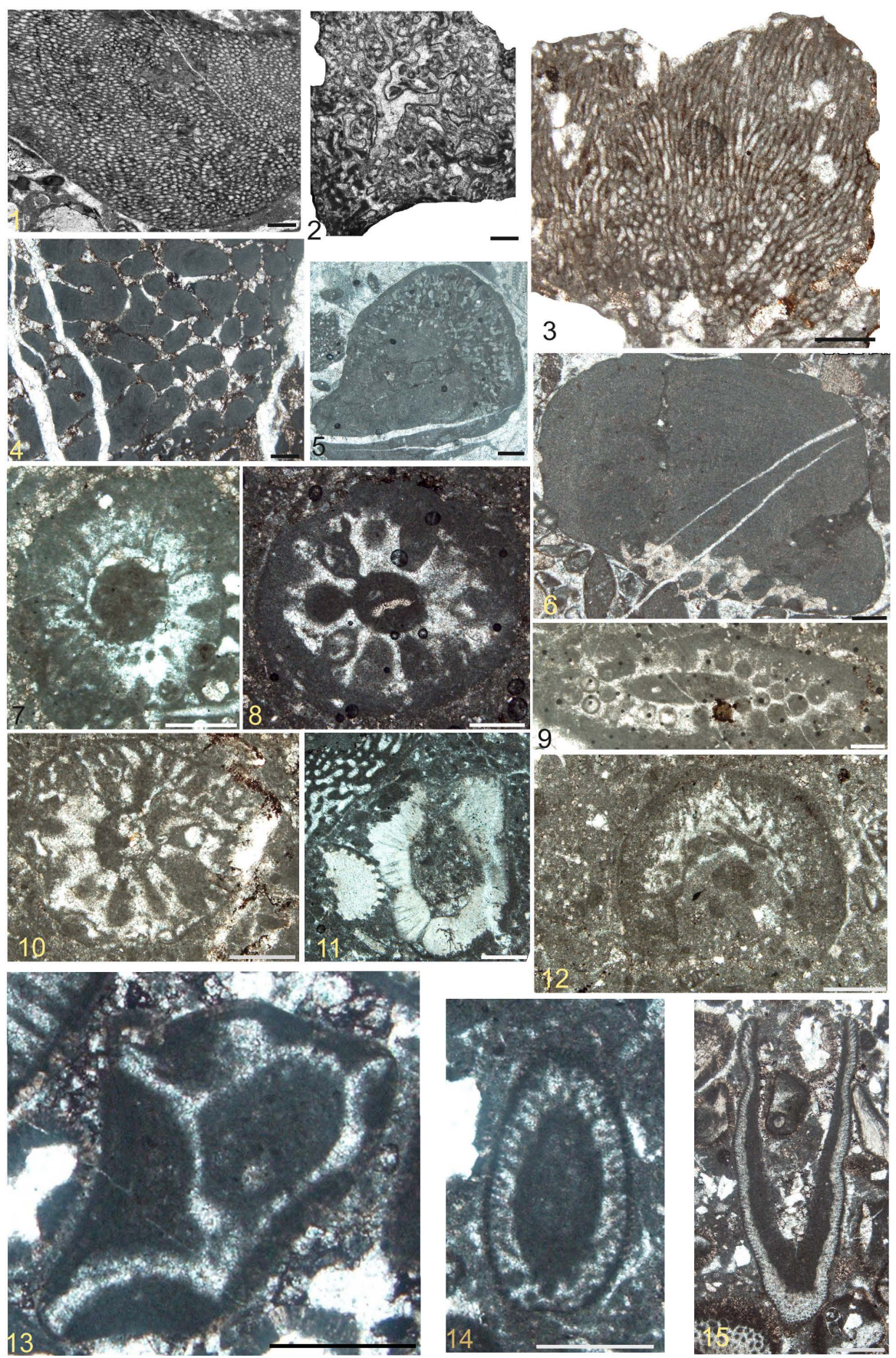

Plate 3. 1. cayeuxia anae. longitude slightly oblique section, 2. Halimeda sp. longitude slightly oblique section, 3. Rivularia sp. longitude slightly oblique section, 4. Rivularia sp. longitude slightly oblique section, 5. Udotea flabellum. longitude slightly oblique section, 6. Marinella cf. yogoslavica. longitude slightly oblique section, 7. Actinoporella sp. oblique section, 8. Montiella elitzae. longitude slightly oblique section, 9. Montiella sp., longitude slightly oblique section, 10. Acroporella sp? transverse section, 11. Salpingoporella cf.dinarica. longitude slightly oblique section, 12. Arabicodium sp. transverse oblique section. 13. Kopedagaria sphaerica. transverse-oblique section, 14. Boueina sp. longitude-slightly oblique section, 15 . Permocalculus minutus. Longitude slightly oblique section. Scale bar represent, $0.3 \mathrm{~mm}$. 


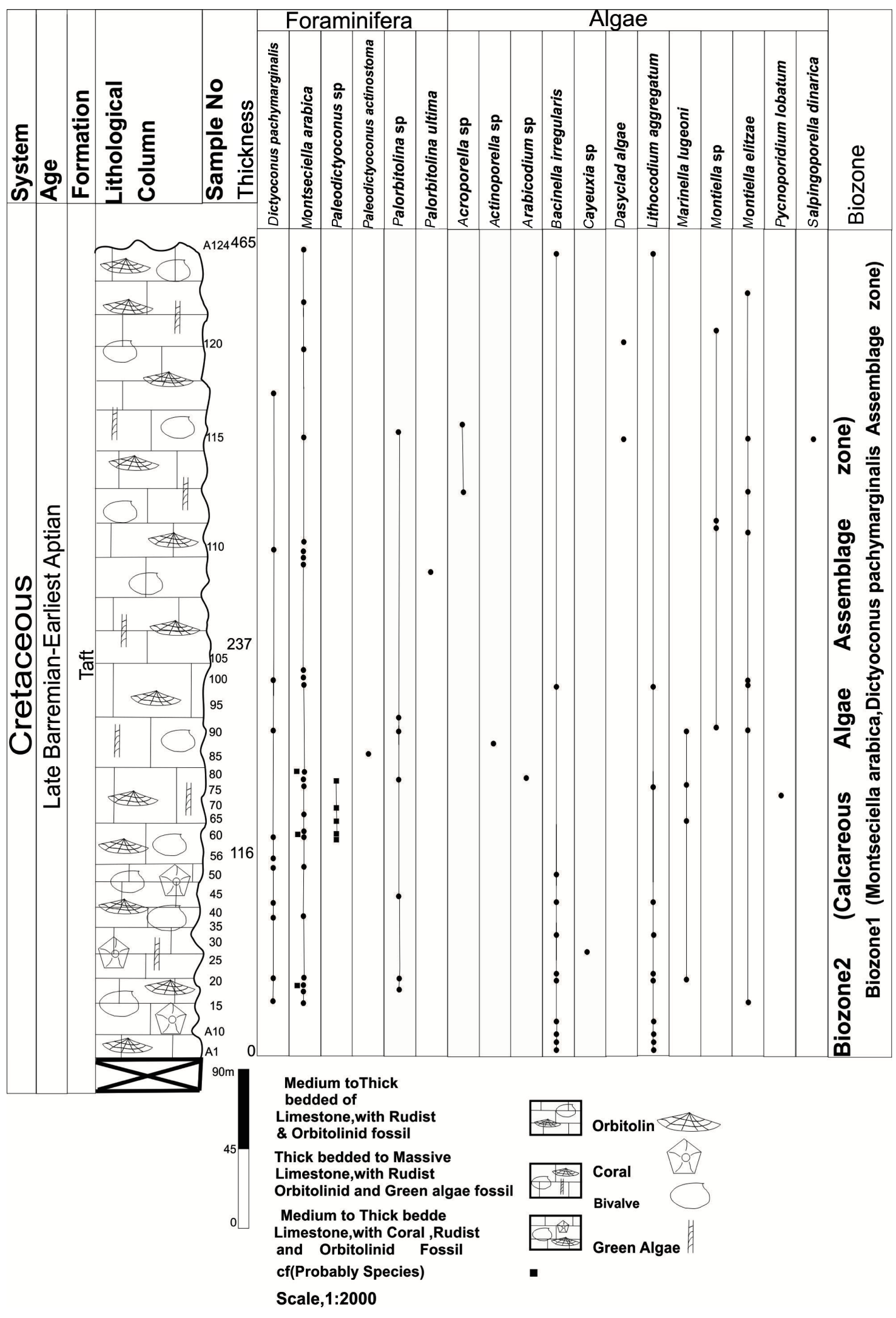

Figure 4. Biostratigraphic diagram of Ab anbar section. 


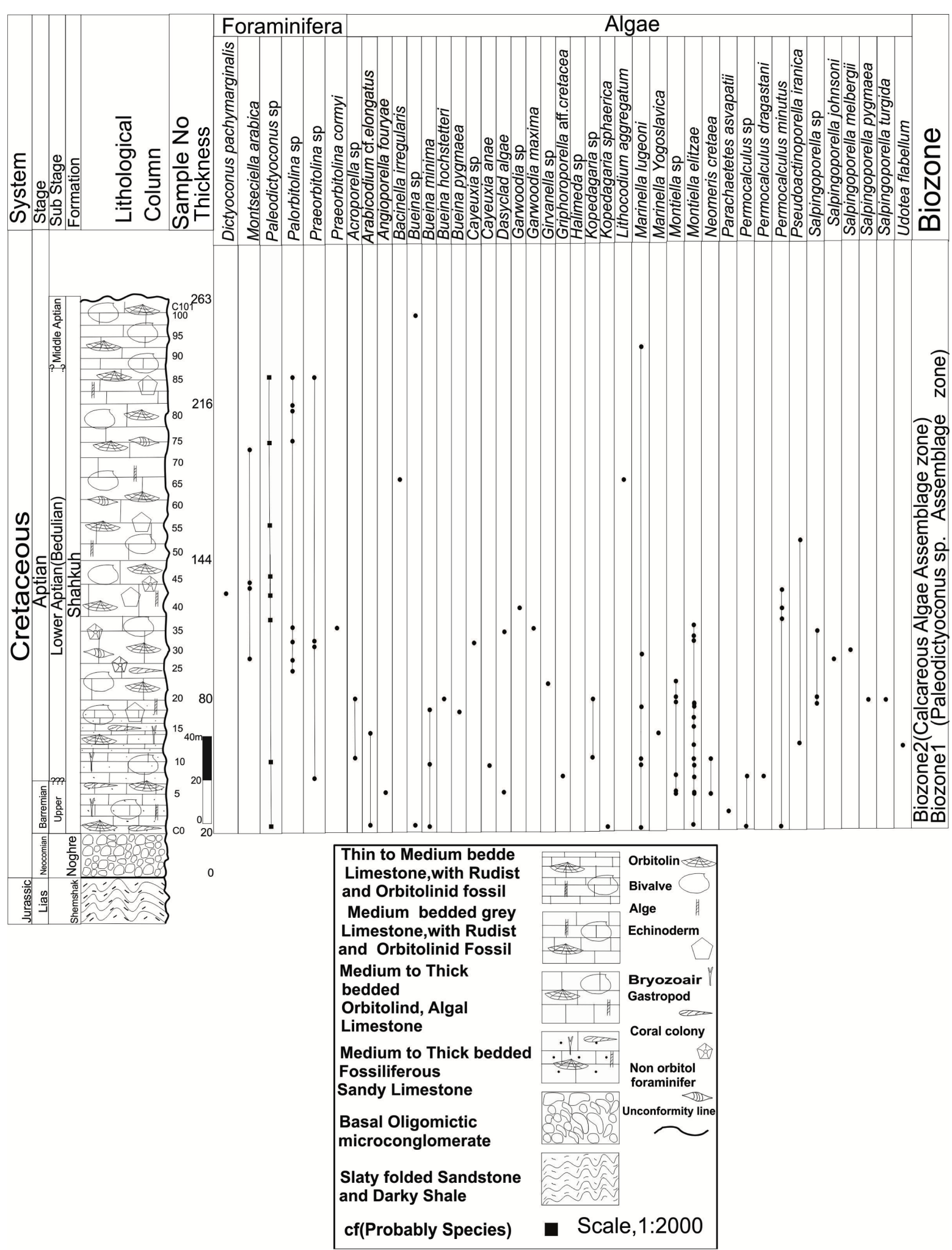

Figure 5. Biostratigraphic diagram of Chah palang section.

Biozone 1: also recognised as "Orbitolinid Biozone" include of (Montseciella arabica, Dictyoconus pachymarginalis, Praeorbitolina cormyi, cf. Paleodictyoconus sp., Praeorbitolina sp., Palorbitolina sp., Assemblage 
zone).

Biozone 2: also recognised as “Algal Biozone” include of (Acroporella sp., Arabicodium cf. elongates, Augioporella cf. fouryae, Bacinella irregularis, Bueina sp., Boueina cf. hochstetteri, Boueina minima, Bueina cf. pygmaea, Cayeuxia sp., Cayeuxia anae, Garwoodia sp., Garwoodia cf. maxima, Girvanella sp., Griphoporella aff. Cretacea, Halimeda sp., Kopedagaria sp., Kopedagaria sphaerica, Lithocodium aggregatum, Marinella sp., Montiella elitzae, Marinella lugeoni, Marinella cf. yogoslavica, Neomeris cf. cretacea, Parachaetetes asvapatii, Permocalculus sp., Permocalculus dragastani, Permocalculus minutes, Pseudoactinoporella iranica, Salpingoporella sp., Salpingoporella cf. johnsoni, Salpingoporella pygmaea, Salpingoporella mehlbergii, Salpingoporella aff. Turgida, Udotea flabellum, Assemblage zone).

Orbitolinid Biozone: This biozone is marked by the first appearance of cf. Paleodictyoconus sp. (Plate 1, F.3, 9, 12). Lithologically is characterized by medium- to thick-bedded cream to grey limestone. Benthic foraminiferal taxa (Orbitolinid Family) are well distributed in this biozone. The Common foraminiferal association of this biozone includes in: Montseciella arabica, Dictyoconus pachymarginalis, Praeorbitolina cormyi, cf. Paleodictyoconus sp., Praeorbitolina sp., Palorbitolina sp.

The Dictyoconus pachymarginalis (Plate 1, F.2, 4, Plate 2, F.5) as index Orbitolina reported by many autors from many localities, such as Schroeder [6] in first time reported this species from Alborz Mountains and Aptian- Lower Albian time purpose for this species, Masse [13], reported this species from NE Spain with purpose age of Lower Gargasian, Yazdi-Moghadam [7] also Roozbahani [8], reported this species from Central Iran zone, Schlagintweit, [9], reported this species from Taft formation in Herisht section, s and Bedulian-Gargasian age purpose for it, and at least, Schlagintweit [9] reported this Microfauna from upper part of Taft formation in type locality and Lower-Middle Bedulian age purposed for it, and he confirmed that, this Microfauna is index Microfossil of North Neo Tethian area. The Montseciella Arabica (Plate 1, Figs.1, 5-7) as another index Orbitolina, reported by many authors from many localititis, such as Clavel [11], reported this species from south France and Jurra Mountain in Swiss area, and Upper Barremian-Early Lower Aptian in comparison with known Ammonite biozone purpose for this species, also Schroeder [12], reported this species from East of Arabian Plate, s and the Upper Barremian-Early Lower Aptian age proposed for this species, The other index Orbitolin Fossils that present in this Biozone, s have same time such as this two species orbitolin indexes that discussed.

Algal Biozone: This biozone is marked by the first appearance of Montiella elitzae (Plate 3, F.8), Marinella lugeoni (Plate 3, F.8) Pseudoactinoporella cf. iranica (Plate 4, F.10), Permocalculus sp. In stratigraphy column of this section,s (Plate 4, F.1). The common Calcareous Algae of this biozone included of: Acroporella sp., Arabicodium cf. elongates, Augioporella cf. fouryae, Bacinella irregularis, Bueina sp., Boueina cf. hochstetteri, Boueina minima, Bueina cf. pygmaea, Cayeuxia sp., Cayeuxia anae, Garwoodia sp., Garwoodia cf. maxima, Girvanella sp., Griphoporella aff. Cretacea, Halimeda sp., Kopedagaria sp., Kopedagaria sphaerica, Lithocodium aggregatum, Marinella sp., Montiella elitzae, Marinella lugeoni, Marinella cf. yogoslavica, Neomeris cf. cretacea, Parachaetetes asvapatii, Permocalculus sp., Permocalculus dragastani, Permocalculus minutes, Pseudoactinoporella iranica, Salpingoporella sp., Salpingoporella cf. johnsoni, Salpingoporella pygmaea, Salpingoporella mehlbergii, Salpingoporella aff. Turgida, Udotea flabellum.

In base of occurrence and total time range of index Calcareous Algae in this biozone (Montiella elitzae, Kopedagaria sp., Kopedagaria sphaerica, Pseudoactinoporella iranica, Salpingoporella sp., Salpingoporella cf. johnsoni, Salpingoporella pygmaea, Salpingoporella mehlbergii, Salpingoporella aff. Turgida) the late Barremian to early Aptian age suggested for this biozone and this stratigraphy section. Actually, common lithofacies and biofacies of this section comprise benthic grainstone, packstone to wackestone. Well developed benthic biofacies of this section support the lagoon and shoal paleoenvironment of the late Barremian to lower Aptian at investigated area. This stratigraphy section comprises of $263 \mathrm{~m}$ thick-massive and grey to purple bentic limestone.

\subsection{Herisht Biostratigraphy}

The two biozones established by distribution of Orbitolinidae Family and Calcareous Algae in this stratigraphic section are numbered as biozones 1 \& 2 (Figure 6):

Biozone 1: also recognised as “Orbitolinid Biozone” include of (Montseciella arabica, Dictyoconus pachymarginalis, Praeorbitolina cormyi, Praeorbitolina wienandsi, Praeorbitolina claveli, Palorbitolina lenticularis, Paleodictyoconus actinostoma, Mesorbitolina parva, Paleodictyoconus sp., Praeorbitolina sp., Palorbitolina sp. 


\section{Plate 4}

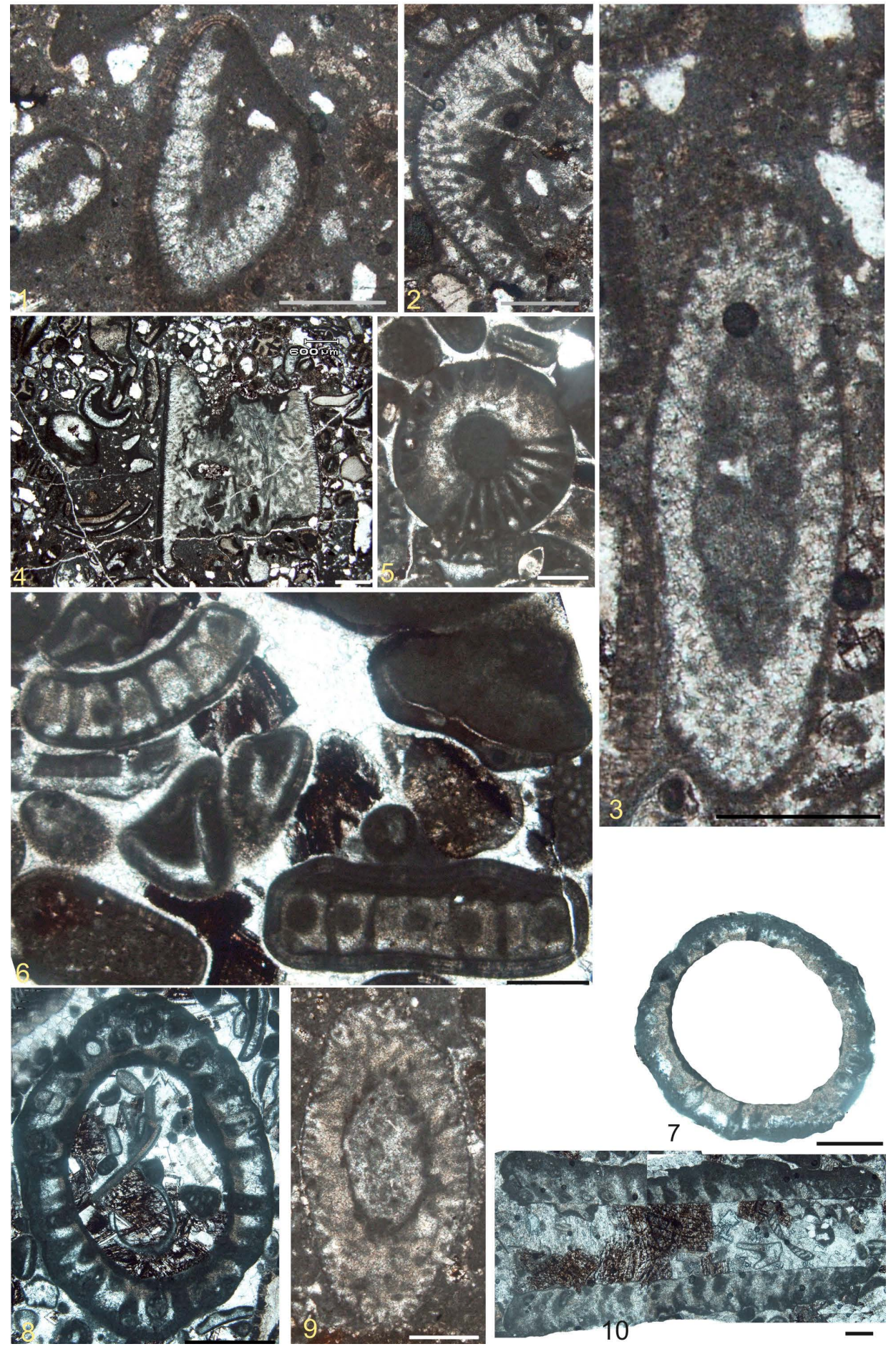

Plate 4. 1. Permocalculus sp. longitude-slightly oblique section, 2. Boueina sp. fragment of transverse section, 3. Boueina aff. minima longitude slightly oblique section, 4._Arabicodium cf. elongatus. longitude section, 5. Angioporella cf. fouryae? transverse oblique section, 6. Neomeris cretacea. fragment of longitude slightly oblique section, 7. Permocalculus dragastani. transverse oblique section,. 8. Griphoporella aff. Cretacea. transverse slightly oblique section, 9. Boueina minima. longitud slightly oblique section, 10. Pseudoactinoporella cf. iranica. longitude section. Scale bar represent, $0.3 \mathrm{~mm}$. 


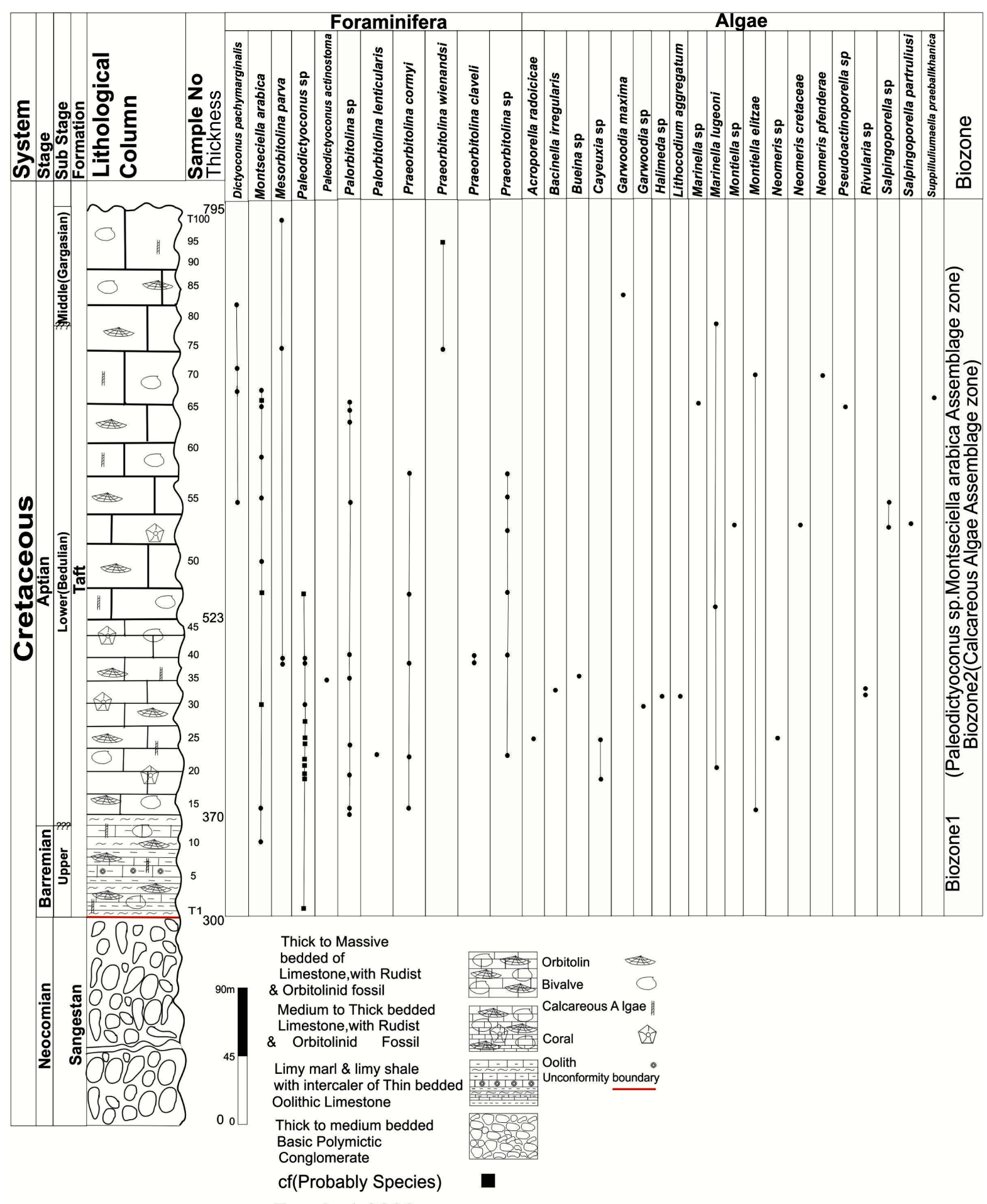

Escale, 1:3000

Figure 6. Biostratigraphic diagram of Herisht section.

Assemblage zone).

Biozone 2: also recognised as "Algal Biozone” include of (Acroporella cf. Radoičićae, Bacinella irregularis, Bueina sp., Cayeuxia sp., Garwoodia sp., Garwoodia cf. maxima, Girvanella sp., Griphoporella aff. Cretacea, Halimeda sp., Lithocodium aggregatum, Marinella sp., Montiella elitzae, Marinella lugeoni, Neomeris sp., 
Neomeris cf. cretacea, Neomeris cf. pfenderae, Pseudoactinoporella sp., Rivularia sp., Salpingoporella sp, Salpingoporella cf. patruliusi, Suppiluliumaella cf. praebalkanica Assemblage zone).

Orbitolinid Biozone: This biozone is marked by the first appearance of cf. Paleodictyoconus sp. (Plate 1, F.3, 9, 12) and Montseciella arabica. (Plate 1, Figs.1, 5-7) Benthic foraminiferal taxa are well distributed in this biozone, and particularly Orbitolinids. The Common foraminiferal association of this biozone consists of Montseciella arabica, Dictyoconus pachymarginalis, Praeorbitolina cormyi, Praeorbitolina wienandsi, Praeorbitolina claveli, Palorbitolina lenticularis, Paleodictyoconus actinostoma, Mesorbitolina parva, Paleodictyoconus sp., Praeorbitolina sp., Palorbitolina sp.

Dictyoconus pachymarginalis (Plate 1, F.2, 4, Plate 2, F.5) as index Orbitolin species, at $110 \mathrm{~m}$ thickness of Taft Formation stratigraphy column at this section is visible. At first, this species reported from Alborz Cretaceous Limestone by Schroeder [6], and Aptian-Lower Albian purposed for it, and so this species reported from SE Spain by Masse [13], and Lower Gargasian purposed for it. Then this species have been reported from central Iran by Yazdi-Moghadam [7] also reported by Roozbahani [8], and so this species have been reported from Taft Formation in Herisht section by Schlagintweit [9], and purposed Beddulian-Gargasian time for it, equal with Praeorbitolina cormyi zone time, and so this species have been reported from Kopedagh by Taherpour Khalil Abad [14]. Finally, this species have been reported from Type locality of Taft Formation by Schlagintweit [10], and he purposed Middle to Upper Bedulian time for it, and he confirmed that this species is index of North Thetis and not reported from Zagros Zone. as results from this text, the Middle Bedulian to Lower Gargasian time purposed for this species,in this section.

The Montseciella arabica (Plate 1, Figs.1, 5-7) species is visible in $310 \mathrm{~m}$ thicknes of Taft Formation stratigraphy column of this section. This species reported by many autors from many locality, such as Clavel [11], reported from south France and Jurra Mountain in Swiss area, with propose age of Upper Barremian-Early Lower Aptian in comparison with known Ammonite biozone, also Schroeder [12] reported this Microfauna from East of Arabian Plate, $\mathrm{s}$ and purposed the Upper Barremian-Lower Bedulian even early middle Bedulian age.

Palorbitolina sp. (Plate 1, F.8) has Parallel persence with Montseciella arabica and is visible in $300 \mathrm{~m}$ of Taft Formation stratigraphy column of this section. Presenting of this genous in time with Montseciella arabica , Dictyoconus pachymarginalis, Praeorbitolina cormyi and Mesorbitolina parva, results lower to upper Bedulian age for this genus.

Praeorbitolina cormyi (Plate 2, F.1, 8) is visible in $180 \mathrm{~m}$ thicknes of Taft Formation stratigraphy column of this section. this species reported from south Thetis province by Schroeder [12], and Middle to Upper BedulianGargasian time purposed for it, and so Schlagintweit [9], reported this species from this section and Lower to upper Bedulian age purposed for this species. At least with notice above discussion and accompaniment of a few index orbitolinida such as Montseciella arabica and Dictyoconus pachymarginalis with this species, The lower to upper Bedulian age purposed for this species in this section.

Similar to above orbitolinid species that recognized stratigraphy age in attention to position of species in section stratigraphy column and reported from other locality of world, The Lower Bedulian age purposed for $\mathrm{Pa}$ lorbitolina lenticularis (Plate 2, F.9) in this section stratigraphy column, and Upper Bedulian-Early Gargasian purposed for Praeorbitolina cf. wienandsi (Plate 2, F.7) in this section.

Praeorbitolina claveli (Plate 2, F.2) reported by Schlagintweit [9] from this section for the first time and named it in honor of Professor Bernard Clavel, and purposed Lower Bedulian for it.

As Mesorbitolina parva (Plate 2, Figs.3, 6, 8) presents in accompany with Montseciella arabica in section stratigraphy column, in spite of reported by Schroeder et al. 2010, from south of Thetys province and Lower Gargasian-Lower Clansayesian age proposed for it, but in attention of position of this species in section stratigraphy column and accompined with index orbitolinid, the Middle Bedulian-Lower Gargasian purposed for this species. In aim of this species, as resulted we recognized the upper boundries of this section stratigraphy column.

The lithologic characteristics of this Biozone consists of cream and grey medium to thick bedded limestone with a thickness of $465 \mathrm{~m}$. based on age of index microfossils such as Dictyoconus pachymarginalis, Montseciella arabica, and Praeorbitolina cormyi, and presence of this microfaunas in contemporaneous condition, the age of this biozone is suggested as late Barremian to early middle Aptian (Figure 6).

Algal Biozone: This biozone is marked by the first appearance of Montiella elitzae (Plate 3, F.8), Calcareous Algae of this biozone includes in: Acroporella cf. Radoičićae, Bacinella irregularis, Bueina sp., Cayeuxia sp., Garwoodia sp., Garwoodia cf. maxima, Girvanella sp., Griphoporella aff. Cretacea, Halimeda sp., Lithocodium 
aggregatum, Marinella sp., Montiella elitzae, Marinella lugeoni, Neomeris sp., Neomeris cf. cretacea, Neomeris cf. pfenderae, Pseudoactinoporella sp., Rivularia sp., Salpingoporella sp, Salpingoporella cf. patruliusi, Suppiluliumaella cf. praebalkanica.

In base of Assemblage Algal Biozone that study in this section, and age range of special index Calcareous Algae, such as Montiella elitzae,., Salpingoporella sp. (Plate 5, F.3), Salpingoporella cf. patruliusi (Plate 5, F.10), Suppiluliumaella cf. praebalkanica (Plate 5, F.11) and etc, the late Barremian to early Middle Aptian age

\section{Plate 5}
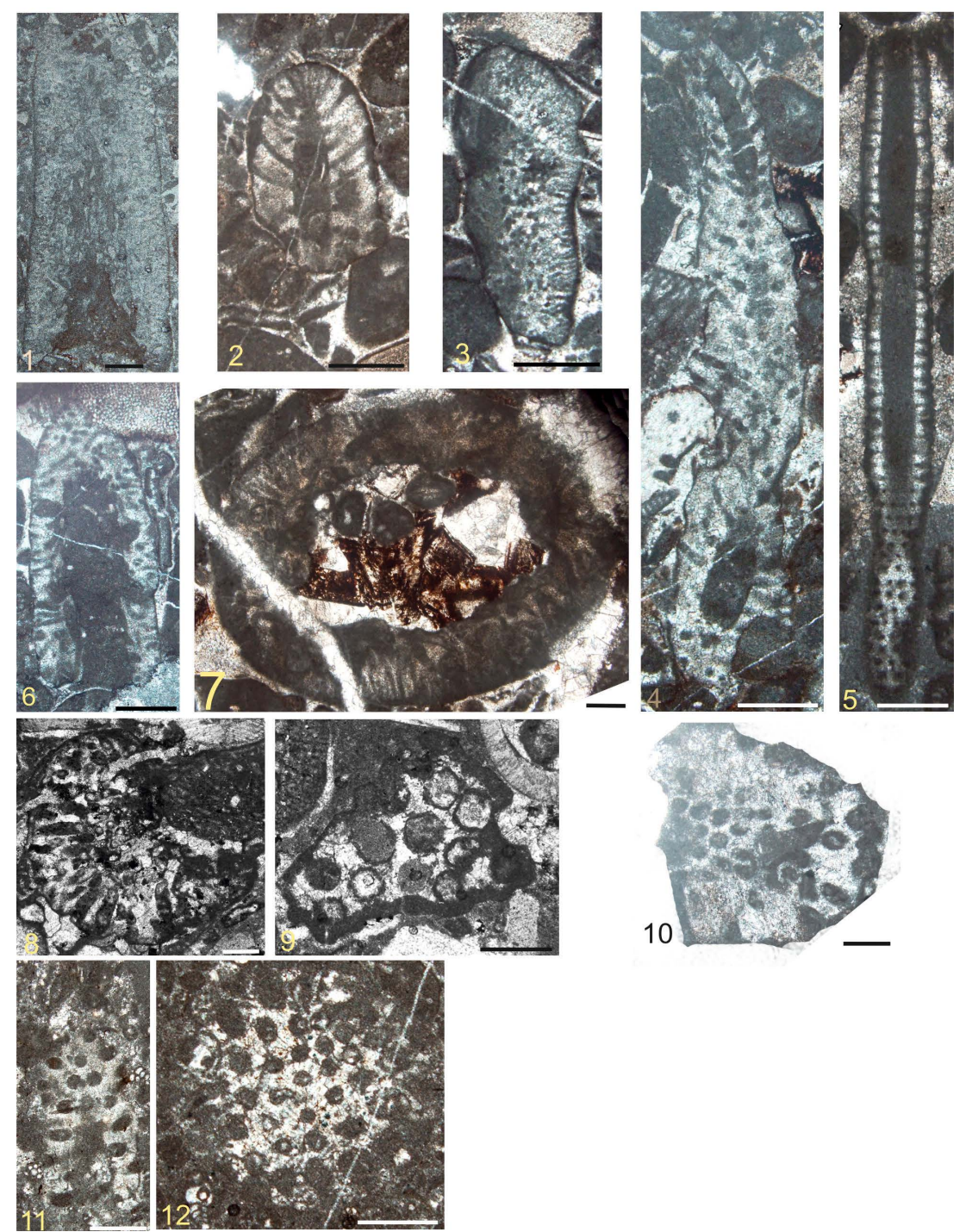

Plate 5. 1. Bueina pygmaea. fragment of longitude slightly oblique section, 2. Salpingoporella pygmaea. fragment of longitude slightly oblique section, 3. Salpingoporella sp., fragment of longitude slightly oblique section, 4. Salpingoporella turgida. Longitude slightly oblique section, 5. Salpingoporella mehlbergii. fragment of longitude slightly oblique section, 6. Bueina hochstetteri. fragment of longitud slightly oblique section, 7. Salpingoporella cf. johnsoni. transverse oblique section, 8. Acroporella cf. radoicicae. fragment of transverse-slightly oblique section, 9. Neomeris sp., fragment of longitude-slightly oblique section, 10. Salpingoporella cf. patruliusi. fragment of longitude slightly oblique section, 11 . Suppiluliumaella cf. praebalkanica. longitude slightly oblique section, 12: Neomeris cf. pfenderae. fragment of longitude-slightly oblique section. Scale bar represent, $0.3 \mathrm{~mm}$. 
is suggested for this biozone. Also, the late Barremian to Early Middle Aptian purposed for this stratigraphy section, that actually confirmed this age by Orbitolinid Biozone, and as a resulted, this age can suggested for this stratigraphy section. Actually, common lithofacies and biofacies of this section comprise grainstone and packstone to wackestone. Well developed benthic biofacies in this section support the lagoon and shoal paleoenvironment at late Barremian to Early Middle Aptian in the investigated area. This section comprise of $495 \mathrm{~m}$ thin bedded calcareous marl and shale in lower part and thick to massive grey to purple bentic limestone in upper part (Figure 6).

\section{Conclusions}

In this study:

We investigated Early Cretaceous benthic associations (foraminifera and calcareous algae) of shallow tropical-water platform environments. [15] As an area of study, we selected a segment of the Cenral Iran zone, which represents a typical, unattached, isolated (Upper Mesozoic) carbonate platform succession.

Our analyses of the microfossil associations have allowed us to establish a detailed biostratigraphical data, such as:

1) The 9 species from 6 genuses of benthic foraminifera (Orbitolinidae Family) and 31 species of calcareous algae from 16 genuses were recovered in this study. These species have restricted stratigraphical ranges, evolving rapidly and becoming extinct suddenly. They are also abundant and have a widespread distribution. This recognized taxa includes in: Dictyoconus pachymarginalis, Montseciella arabica, Mesorbitolina parva, Paleodictyoconus actinostoma, Palorbitolina lenticularis, Praeorbitolina cormyi, Praeorbitolina cf. wienandsi, Praeorbitolina claveli, Palorbitolina ultima, from Orbitolinidae Family and, Acroporella cf. Radoičićae, Arabicodium cf. elongates, Augioporella cf. fouryae, Bacinella irregularis, Boueina cf. hochstetteri, Boueina minima, Bueina cf. pygmaea, Garwoodia cf. maxima, Griphoporella aff. Cretacea, Kopedagaria sp., Kopedagaria sphaerica, Lithocodium aggregatum, Marinella sp., Montiella elitzae, Marinella lugeoni, Marinella cf. yogoslavica, Neomeris cf. cretacea, Neomeris cf. pfenderae, Parachaetetes asvapatii, Permocalculus sp, Permocalculus dragastani, Permocalculus minutes, Pseudoactinoporella sp., Pseudoactinoporella iranica, Pseudoactinoporella cf. iranica, Pycnoporidium lobatum, Rivularia sp., Salpingoporella sp., Salpingoporella cf. patruliusi, Salpingoporella cf. johnsoni, Salpingoporella pygmaea, Salpingoporella mehlbergii, Salpingoporella aff. Turgida, Salpingoporella cf .dinarica, Suppiluliumaella cf. praebalkanica, Udotea flabellum from Calcareous Algae.

2) The two Biozone ,one from Orbitolinidae Family, and other from Calcareous Algae, recognized in any three stratigrapht column of sections that were selected for this study, in example Abanbar, Herisht and etc.

3) As cronostratigraphy result, the sedimentation of Cretaceous Sea in Abanbar, Chahpalang and Herisht area started from Upper Barremian and continued to Lower-Middle Aptian, in this long time, the thin to thick and massive limestones belong to the Taft and Shahkuh Formation at Yazd Block deposited.

4) As microfacies and sedimentary environment result, the cretaceous sediments belong to the Taft and Shahkuh Formation at Yazd Block as grainstone diversity, from wackestone to packstone, seldom granstone, and rarely boundstone are visible and deposited at inner ramp in shoal to lagoon facies belt.

\section{References}

[1] Wilmsen, M., Fürsich, F.T. and Majidifard, M.R. (2010) Cretaceous Stratigraphy and Facies Development of the Yazd Block, Khur Area, Central Iran. STRATI 2010, Paris. Abstract-Volume, 249-250.

[2] Wilmsen, M., Fürsich, F.T. and Majidifard, M.R. (2013) The Shahkuh Formation, a Latest Barremian-Early Aptian Carbonate Platform of Central Iran (Khur Area, Yazd Block). Cretaceous Research, 39, 183-194.

[3] Aghanabati, A. (2004) The Geology of Iran. Geological Survey of Iran, 389 p. (In Persian)

[4] Aistov, L., Melnikov, B., Krivyakin, B., Morozov, L. and Kiristaev, V. (1984) Geology of the Khur Area (Central Iran). Explanatory Text of the Khur Quadrangle Map 1:250,000, V/O Technoexport, Report 20, 1-130.

[5] Nabavi, M. (1972) Lower Cretaceous Deposits in the Taft-Yazd and Khor Area. Geological Survey of Iran Report 106, $127 \mathrm{p}$.

[6] Schroeder, R. (1965) Dictyoconus pachymarginalis n.sp. aus dem Apt des Elburz-Gebirges (Nord-Iran): Studien über primitive Orbitolinidae III. Vol. 58, Eclogae Geologiace Helvetiae, Basel, 976-979.

[7] Yazdi-Moghadam, M. and Amiri, F. (2010) Lower Cretaceous Agglutinated Larger Benthic Foraminifera from the Sarvestan Section, South of Esfahan, Iran. The 1st International Applied Geological Congress, Department of Geology, 
Azad University Mashad Branch, Iran, 26-28 April 2010, 976-980.

[8] Roozbahani, P.R. (2012) Lithostratigraphy and Biostratigraphy of the Lower Cretaceous of the Jalmajird Area (Northeast of Khomeyn, Central Iran Basin), Iran. GEO. ALP, 9, 48-58.

[9] Schlagintweit, F., Bucur, I.I., Rashidi, K. and Saberzadeh, B. (2013) Praeorbitolina claveli n. sp. (Benthic Foraminifera) from the Lower Aptian (Bedoulian) of Central Iran. Carnets de Géologie-Notebooks on Geology, Letter 2013/04, 255272.

[10] Schlagintweit, F. and Wilmsen, M, (2014) Orbitolinid Biostratigraphy of the Top Taft Formation (Lower Cretaceous of the Yazd Block, Central Iran). Cretaceous Research, 49, 125-133. http://dx.doi.org/10.1016/j.cretres.2014.02.016

[11] Clavel, B., Conrad, M.A., Busnardo, R., Charollais, J. and Granier, B. (2013) Mapping the Rise and Demise of Urgonian Platforms (Late Hauterivian-Early Aptian) in Southeastern France and the Swiss Jura. Cretaceous Research, 39, 29-46. http://dx.doi.org/10.1016/j.cretres.2012.02.009

[12] Schroeder, R., Buchem, F.S.P., van Cherchi, A., Baghbani, D., Vincent, B., Immenhauser, A. and Granier, B. (2010) Revised Orbitolinid Bio-Stratigraphic Zonation for the Barremian-Aptian of the Eastern Arabian Plate and Implications for Regional Stratigraphic Correlations. GeoArabia Special Publication 4, Manama, 49-96.

[13] Masse, J.P., Arias, C. and Vilas, L. (1992) Stratigraphy and Biozonation of a Reference Aptian-Albian. Tethyan Carbonate Platform Succession: The Sierra del Carche Series (Oriental Prebetic Zone-Murcia, Spain). Schriftenreihe der Erdwissenschaft-Lichen Kommission, 9, 201-221.

[14] Khalil Abad, M.T., Schlagintweit, F., Vaziri, S.H., Aryaei, A.A. and Ashouri, A.R. (2013) Balkhania Balkhanica Mamontova, 1966 (Benthic Foraminifer) and Kopetdagaria Sphaerica Maslov, 1960 (Dasycladale Alga) from the Lower Cretaceous Tirgan Formation of the Kopet Dagh Mountain Range of NE-Iran and Their Palaeobiogeographic Significance. Facies, 59, 267-285.

[15] Bucur, I.I., Rashidi, K. and Senowbari-Daryan, B. (2012) Early Cretaceous Calcareous Algae from Central Iran (Taft Formation, South of Alibad, Near Yazd). Facies, 58, 605-636. 